\title{
Visiting Patients at Home: Reasons and Efficiency of Dental House Calls
}

\author{
Maria Kretsch*, Ursula Gresser \\ Ludwig-Maximilians University of Munich, Munich, Germany \\ Email:"mariakretsch@gmx.de, ursulagresser@email.de
}

Received 30 September 2015; accepted 11 November 2015; published 17 November 2015

Copyright (C) 2015 by authors and Scientific Research Publishing Inc.

This work is licensed under the Creative Commons Attribution International License (CC BY).

http://creativecommons.org/licenses/by/4.0/

(c) (i) Open Access

\section{Abstract}

This retrospective study analyzes indications for house calls by dentists in a domiciliary setting. Its database consists in 69 visits made by a dentist office in Munich from 1998 to 2013 at the homes of 29 non-institutionalized seniors ( $\geq 62$ years old, 15 females, 14 males, average age 83.7 years old). The analysis focused on the patients' general state of health, their dental and oral health, the kinds of dental treatments administered, as well as economic aspects and the quantitative development in the frequency of house calls during the study period. The most frequent preexisting conditions that made a house call necessary were cardiovascular illnesses $(60 \%)$ and dementia diseases (36\%). Multi-morbidity, dependency on care, accessibility issues, and frailty because of advanced age played a central role. The patients' oral health was acceptable, with the exception of those with dementia diseases, who were more frequently toothless (40\% versus $5.6 \%)$ and had a higher percentage of carious and decayed teeth (26.3\% versus $10.3 \%)$. The most frequent procedures were treatments for denture sores and the repair of removable dentures $(53.6 \%)$. The main focus was on reparative dentistry. The average house call took 37 minutes including travel time. Thus, the time needed was a multiple of the time necessary for treatment in the dental office. The lack of economic efficiency may be the reason why many dentists in Germany hesitate to make house calls. Despite the introduction of additional fees for the treatment of patients in need of long-term care on April 1, 2013, the number of house calls is low and increases only slowly. At the same time, the need for house calls will rise in the future due to an increasing proportion of elderly persons in the population and a decline in the percentage of toothless elderly.

\section{Keywords}

Dentist House Calls, Non-Institutionalized Seniors, Reparative Dentistry, High Time Expenditure

${ }^{*}$ Corresponding author. 


\section{Introduction}

The number of seniors in need of long-term care in Germany was around 2.5 million in 2011. The majority (70\%) received care at home [1]. Frail and functionally dependent seniors face particular difficulties in accessing dental care. Dentists hesitate to make house calls with seniors firstly because of low payments in the face of high costs for running a dental office [2] and secondly because they are afraid of medical complications in the treatment of these patients [3]. However, especially the elderly have a greater demand for dentist house calls because they incur a greater risk of dental diseases due to age-related physiological changes, chronic diseases, and the use of diverse medications [4]. This need will increase further because of the demographic development and the reduction in edentulousness [5].

The established system of dental care puts the elderly and the disabled at a disadvantage because these groups are often not able to take the initiative to seek treatment themselves [6]. Poor general health and multi-morbidity can even pose an obstacle to them for visiting a dentist. Thus, the more money and time seniors spend on seeing physicians and using medication, the less do they make use of dental services. Also, limitations in the activities of daily living (ADL) correlate with a lower rate of dentist visits [7].

Dental and oral illnesses that are not treated can endanger the general health, and cause or aggravate respiratory [8]-[11] and cardiovascular diseases [12]. They can also negatively influence speech, social participation, and integration in society [13]. Recent decentralized concepts of care can improve the situation. Especially patients with dementia diseases profit from receiving treatment in a domiciliary environment they are accustomed to, because there they feel more at ease and have a higher degree of control over the situation [14].

\section{Material and Methods}

The study was designed as a retrospective analysis and is based on data from the author's dental practice. It analyzed data of patients who received one or more house calls between 1998 and 2013. The approval was given by the patients. Statistical analysis was done by the author. For the demographic characteristics of the patients, see Table 1 and Table 2.

The following inclusion criteria had to be met by patients for their data to be included:

- Age of 62 or older;

- No longer part of the workforce;

- House call(s) demanded by patient, relative, or caregiver;

- House call(s) in a non-institutional, domiciliary setting.

A literature research was done from February to October 2014. The following search engines were utilized: Google, Google scholar and PubMed.

Table 1. Gender and age: distribution of the 29 patients (1. house call).

\begin{tabular}{ccccccc}
\hline Life Decades & \multicolumn{2}{c}{ Total $\mathbf{n}=\mathbf{2 9}$} & \multicolumn{2}{c}{ Male n = 14 } & \multicolumn{2}{c}{ Female $\mathbf{n}=\mathbf{1 5}$} \\
\hline Age & Number & Percent & Number & Percent & Number & Percent \\
\hline & 29 & $100 \%$ & 14 & $48.3 \%$ & 15 & $51.7 \%$ \\
$70-69$ & 1 & $3.4 \%$ & 0 & $0.0 \%$ & 1 & $6.7 \%$ \\
$80-89$ & 6 & $20.7 \%$ & 4 & $28.6 \%$ & 2 & $13.3 \%$ \\
$90-99$ & 17 & $58.6 \%$ & 8 & $57.1 \%$ & 9 & $60.0 \%$ \\
\hline
\end{tabular}

Table 2. Life forms: distribution of the 29 patients (1. house call).

\begin{tabular}{|c|c|c|c|c|c|c|}
\hline \multirow{2}{*}{ Life Forms } & \multicolumn{2}{|c|}{ Total $n=29$} & \multicolumn{2}{|c|}{ Male $n=14$} & \multicolumn{2}{|c|}{ Female $n=15$} \\
\hline & Number & Percent & Number & Percent & Number & Percent \\
\hline & 29 & $100 \%$ & 14 & $48.3 \%$ & 15 & $51.7 \%$ \\
\hline Living alone & 6 & $20.1 \%$ & 1 & $7.1 \%$ & 5 & $33.3 \%$ \\
\hline Life Partner & 18 & $62.1 \%$ & 12 & $85.7 \%$ & 6 & $40.0 \%$ \\
\hline Family Network (Daughter) & 5 & $17.2 \%$ & 1 & $7.1 \%$ & 4 & $26.7 \%$ \\
\hline
\end{tabular}




\section{Results}

\subsection{Description of Sample Group}

The number of women (15) and of men (14) was almost equal. Average age of men was 84 years and plus half a year above that of the female participants. 15 patients were 85 or older. $34.5 \%$ of the patients had private health insurance, and their percentage was thus more than three times as high as in the general population. Only every fifth patient and more women than men lived alone.

More than half of the 29 patients visited at home were limited in their mobility so severely that they could not receive outpatient medical care without the use of aids such as wheelchairs or stretchers. For $62 \%$ of the study group, barriers in their personal living space were almost as decisive a factor preventing them from seeking outpatient care as age-related frailty or limitations due to diseases.

\subsection{General State of Health}

The number of different illnesses ranged from 0 to 8 . At more than $60 \%$, cardiovascular diseases were the most frequent in the patients, and every third patient also suffered from the consequences of a stroke. Corresponding therapy had led to a medication-induced increase in bleeding tendency in almost half of the patients.

Second most frequent were diseases leading to limitations in daily living skills (dementia, cognitive limitations, aphasia). More than one third of the participants were affected by such diseases.

Approximately every fifth study participant suffered from diseases of the joints and from tumor illnesses while diabetes and neurological diseases (14\% each) and kidney insufficiency $(7 \%)$ played a minor role. The majority of patients (57\%) also suffered from diverse additional diseases. The median of different diseases in male study participants was 3.4 and thus slightly higher than the median for women (2.8).

\subsection{Dental and Oral Health}

On average, the participants had not seen a dentist in almost 20 months, in the case of patients with dementia this period was four months longer. Only five patients had not seen a dentist in three or more years.

Almost $90 \%$ of the patients had removable prostheses. Five patients (17.2\%) were completely edentulous; all of them had prosthetic fittings. The average number of teeth was 9.1. On average, men had 2.2 teeth more than women. On average, there were more teeth in the lower jaw (5.8) than in the upper jaw (3.3).

Dental health was considerably worse in the 10 patients with dementia than in the other patients:

- Complete Edentulousness (40\% versus 5.6\%);

- Median number of teeth (7.6 versus 14.5);

- Overall percentage of carious teeth and of teeth destroyed by caries (26.3\% versus $10.3 \%)$;

- Percentage of patients with carious teeth and teeth destroyed by caries (66.7\% versus $29.4 \%)$.

\subsection{Administration of House Calls and Dental Treatments}

The dentist used her own car for all house calls to transport material for treatments and diagnoses. In general, the time effort was high (on average 37 minutes per visit). This included an average of 15 minutes driving time. The median one-way distance was 6.02 kilometers. 23 of the 29 patients had visited the dental practice before so that the dental status and their prosthetic fittings were known.

One of the treatments frequently performed during house calls, the adaptation of the prosthesis to avoid sores, takes only 5 to 10 minutes if administered in the dental office. For the predominantly prosthetic treatments, the battery operated micro motor (Bravo Portable II, Hager \& Werken) was used, which could be fitted with different straight and contra-angled handpieces. There was no portable $\mathrm{X}$-ray equipment and no pressured air, water cooling, or suction so that the kinds of treatments administered were limited.

Most frequent were treatments of denture sores, restoration of removable dentures such as relining of prostheses, prostheses repairs, and activation of holding elements for prostheses (53.6\%). There were four visits with extractions and at six house calls preparatory measures for new prostheses were taken.

Follow-up treatments after extractions were administered 11 times. More complex and time-consuming treatments were implemented in the dental practice, especially fillings, $x$-rays, root canal treatments, difficult extractions, and fitting crowns on teeth. In each of the 29 patients and in all of the 69 house calls a need for 
treatment was ascertained; all in all, 97 treatments were administered, for the distribution see Figure 1.

\section{Discussion}

\subsection{Characteristics of Study Participants}

The group analyzed for the present study differs from groups analyzed in other studies through an almost equal distribution of sexes, a high socio-economic status, with more than one third of the participants privately insured, and a low percentage (21\%) of individuals living alone or not with family members while participants in other studies were predominantly institutionalized, housebound, and female [15]-[19].

The inclusion criteria for the study demanded that participants had actively asked for a house call and, therefore, excluded seniors who were no longer able to recognize a need for treatment and who lacked corrective support of family members or caregivers that could have taken initiative on their behalf. Individuals living in retirement homes or being cared for by ambulant nursing services lack the social network provided by family members to a greater extent than those who despite limitations can still be cared for at home [20].

\subsection{General State of Health}

The results of the present study were congruent with findings in the literature with respect to a predominance of cardiovascular diseases and permanent functional limitations due to strokes [3] [21] [22]. Dementia diseases that make very often help from other people necessary occur significantly more frequently in institutionalized seniors (58\%) [21] than in the present study's cohort of patients, who live at home.

However, the present study's participants suffered more frequently from tumor diseases (21.4\%) and neurological illnesses (14.3\%). In Germany, cancer is the second most frequent cause of death (25\%) and the numbers show a rising trend [23]. Neurological diseases such as multiple sclerosis or Parkinson's disease lead particularly frequently to limitations in mobility and may thus make it necessary for persons falling ill with these diseases to receive house calls.

\subsection{Dental and Oral Health}

What was striking about the findings was the low prevalence of complete toothlessness (17.2\%), which despite the advanced average age of the patients was lower than in all other non-Asian studies [24]-[28]. In contrast, the Fourth German Oral-Health Study (DMS IV) states a prevalence of 22.6\% [29]. Many patients with full dentures believe that because of the absence of teeth they don't need any dental care [30]. Edentulousness is more

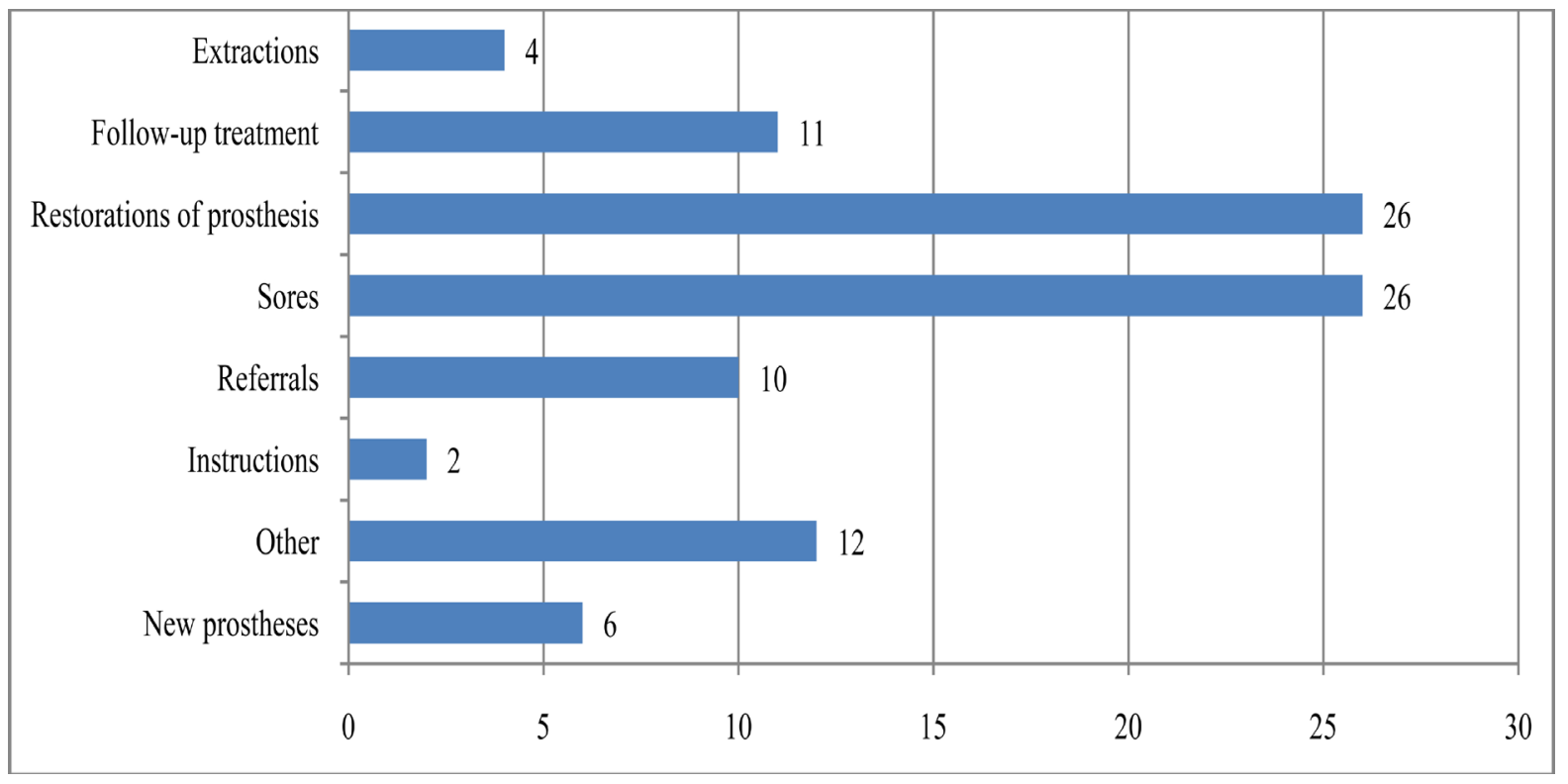

Figure 1. Type and distribution of 97 treatments administered to 29 patients during 69 house calls from 1998 to 2013. 
prevalent among institutionalized seniors and in rural areas partly because of the lesser quantitative availability of dental care [24] [25].

While all five completely toothless patients in the present study were fitted with prostheses, a study in Bari (Italy) found that among edentulous institutionalized seniors more than half did not have dentures at all [27]. Also with respect to carious diseases, the present results indicate an above-average health in an international context: almost $15 \%$ of the teeth were carious or destroyed by caries at the time of the first house call. In contrast, Corsalini et al. [27] and Katsoulis et al. [28] found in their study cohorts in Bari and, respectively, in Bern (Switzerland) values more than twice as high. The various health systems in Europe lead to considerable regional differences [26].

The positive results of the present study regarding oral and dental health do not apply to the 10 participants with dementia, 4 of whom were completely edentulous. In the remaining six, two thirds (4) had carious teeth or teeth destroyed by caries. A Swiss study confirms the problem: persons suffering from dementia are in worse dental and oral health, they have fewer teeth and the teeth they have are more often affected by caries and by untreated lesions [31]. Therefore, dentists will have to focus this group more intensely in the future.

\subsection{Increasing Need for Dental Treatment at Home}

Based on data of the Panel Dentists' Association (Kassenzahnärztliche Bundesvereinigung, KZBV), the absolute number of house calls by dentists in Germany paid for by statutory health insurance has increased from 490,000 in 2006 to about 725,000 in 2013. Given the relatively constant number of panel dentists (circa 50,000), on average 13.6 house calls per dentist were made in 2013.

The majority of those house calls (70\%) in the same year were paid to patients depending on long term-care and to persons with a disability [32]. No information was available on how those house calls were distributed across patient age groups and settings (domiciliary or institutional).

Questionnaire studies conducted in Belgium and in the region Westfalen-Lippe in Germany come to the conclusion that dentists pay the majority of house calls to institutionalized seniors and that less than one third of house calls are made in a domiciliary setting [33] [34]. Seniors depending on long-term care and living at home are difficult to reach and, therefore, their specific dental care situation has hardly been investigated.

The number of house calls made by the author to seniors in a domestic setting was on average 1.75 per year in the period from 1998 to 2005, but rose from 2006 until 2013 to an average of almost 7 house calls per year. In the case of 19 patients, one visit was sufficient to remedy the dental problem. In a few instances more than one visit was necessary. The fee turnover (2008-2013) was circa 140 euros per hour and was thus significantly lower than the average fee turnover in the states of former West Germany, which was 196 euros in 2006 [35].

The low number of house calls gives evidence of the lack of a systematic decentralized care in Germany [36]. Care is exclusively given by dentists in private practice. Public health services are not involved [12]. While many dental treatments are paid for by private and statutory health insurance, the fees paid to private practioners for house calls do not suffice to cover the cost because of the high expenditure of time and the high cost of maintaining a dental office. One reason is the overregulation of the health system with fixed fees, strict budgets, and limitations due to the professional code of practice as regulated by law [12].

The economic situation may be different for specialized dentist offices that administer several house calls back-to-back and are equipped with a mobile treatment unit which enables them to offer a broader range of treatments.

It may also be economically more efficient to make house calls for institutionalized patients because in a retirement home several patients can be seen consecutively during one visit [37].

\section{Conclusions}

Even in highly developed countries, housebound seniors often receive only emergency treatment. Very often this treatment is administered only to solve acute dental problems and has to be actively demanded. In Germany, a systematic and comprehensive care could only be offered if new concepts were created, such as establishing dental care in geriatric hospitals and involving public health services.

If preventive dental care were financed through the system of statutory health insurance and if preventive treatments were allowed to be rendered by dental assistant staff without the present restrictions, homebound seniors could participate in an up-to-date, prophylactically oriented dentistry. In many cases, even simple treat- 
ment measures would improve the quality of life of immobile patients.

\section{Acknowledgements}

This research is based on the thesis submitted of Maria Kretsch "Zahnärztliche Hausbesuche bei Patienten $\geq 62$ Jahren im häuslichen Setting unter besonderer Berücksichtigung internistischer Erkrankungen und wirtschaftlicher Aspekte” at the Medical Faculty of the Ludwig-Maximilians University of Munich.

\section{References}

[1] Statistisches Bundesamt (2014) Pflegestatistik 2011: Pflege im Rahmen der Pflegeversicherung Deutschlandergebnisse. https://www.destatis.de/DE/Publikationen/Thematisch/Gesundheit/Pflege/PflegeDeutschlandergebnisse522400111900 4.pdf?_blob=publicationFile

[2] Holm-Pedersen, P., Vigild, M., Nitschke, I. and Berkey, D. (2005) Dental Care for Aging Populations in Denmark, Sweden, Norway, United Kingdom and Germany. Journal of Dental Education, 69, 987-997.

[3] Katsoulis, J., Huber, S. and Mericske-Stern, R. (2009) Gerodontologischer Konsiliardienst bei stationären Geriatriepatienten: Allgemeinmedizinischer Zustand (I). Schweizer Monatsschrift für Zahnmedizin, 119, 12-18.

[4] Dolan, T.A., Atchison, K. and Huynh, T.N. (2005) Access to Dental Care among Older Adults in the United States. Journal of Dental Education, 68, 961-974.

[5] Douglass, C.W., Shih, A. and Ostry, L. (2002) Will There Be a Need for Complete Dentures in the United States in 2020? The Journal of Prosthetic Dentistry, 87, 5-8. http://dx.doi.org/10.1067/mpr.2002.121203

[6] Helgeson, M. and Glassman, P. (2013) Oral Health Delivery Systems for Older Adults and People with Disabilities. Special Care in Dentistry, 33, 177-189. http://dx.doi.org/10.1111/scd.12038

[7] Kiyak, H.A. and Reichmuth, M. (2005) Barriers to and Enablers of Older Adults’ Use of Dental Services. Journal of Dental Education, 69, 975-986.

[8] Ishikawa, A., Yoneyama, T., Hirota, K., Miyake, Y. and Miyatake, K. (2008) Professional Oral Health Care Reduces the Number of Oropharyngeal Bacteria. Journal of Dental Research, 87, 594-598. http://dx.doi.org/10.1177/154405910808700602

[9] Azarpazhooh, A. and Leake, J.L. (2006) Systematic Review of the Association between Respiratory Diseases and Oral Health. Journal of Periodontology, 77, 1465-1482. http://dx.doi.org/10.1902/jop.2006.060010

[10] Yoneyama, T., Yoshida, M., Ohrui, T., Mukaiyama, H., Okamoto, H., Hoshiba, K., Ihara, S., Yanagisawa, S., Ariumi, S., Morita, T., Mizuno, Y., Ohsawa, T., Akagawa, Y., Hashimoto, K. and Sasaki, H. (2002) Oral Care Reduces Pneumonia in Older Patients in Nursing Homes. Journal of the American Geriatrics Society, 50, 430-433. http://dx.doi.org/10.1046/j.1532-5415.2002.50106.x

[11] Terpenning, M. (2005) Geriatric Oral Health and Pneumonia Risk. Clinical Infectious Diseases, 40, 1807-1810. http://dx.doi.org/10.1086/430603

[12] Nitschke, I. and Reiber, T. (2007) Gerostomatologie-Eine Herausforderung auch für den Öffentlichen Gesundheitsdienst. Gesundheitswesen, 69, 541-547. http://dx.doi.org/10.1055/s-2007-992770

[13] Nitschke, I. (2005) Experten-Hearing “Präventiver Hausbesuch im Alter”. Conference Präventiver Hausbesuch im Alter, Bonn, Edited by Bundesvereinigung für Gesundheit e.V. http://www.dip.de/fileadmin/data/pdf/material/Dokumentation_Experten_Hearing.pdf

[14] Lee, E.E., Thomas, C.A. and Vu, T. (2001) Mobile and Portable Dentistry. Alternative Treatment Services for the Elderly. Special Care in Dentistry, 21, 153-155. http://dx.doi.org/10.1111/j.1754-4505.2001.tb00245.x

[15] Shahidi, A., Casado, Y. and Friedman, P.K. (2008) Taking Dentistry to the Geriatric Patient: A Home Visit Model. Journal of the Massachusetts Dental Society, 57, 46-48.

[16] Vigild, M. (1987) Denture Status and Need for Prosthodontic Treatment among Institutionalized Elderly in Denmark. Community Dentistry and Oral Epidemiology, 15, 128-133. http://dx.doi.org/10.1111/j.1600-0528.1987.tb00499.x

[17] Benz, C. and Haffner, C. (2009) Zahnmedizin in der Pflege-Das Teamwerk-Projekt. IDZ Information, 4, 1-23.

[18] Nitschke, I., Ilgner, A., Meissner, G. and Reiber, T. (2003) Zahngesundheit von Bewohnern in ländlichen und städtischen Senioreneinrichtungen. Deutsche Zahnärztliche Zeitschrift, 58, 457-462.

[19] MacEntee, M.I. (2006) Missing Links in Oral Health care for Frail Elderly People. Journal of the Canadian Dental Association, 72, 421-425.

[20] Krüger, K. (2008) Mundgesundheit und prothetischer Versorgungsgrad von Senioren in häuslicher Pflege in der Stadt Greifswald. Dr. med. dent. Thesis, Department of Prosthetic Dentistry, Ernst-Moritz-Arndt-Universität, Greifswald. 
[21] McDermott, R., Gillespie, S.M., Nelson, D., Newman, C. and Shah, M.N. (2012) Characteristics and Acute Care Use Patterns of Patients in a Senior Living Community Medical Practice. Journal of the American Medical Directors Association, 13, 260-263. http://dx.doi.org/10.1016/j.jamda.2010.10.007

[22] Scott, T.M., Peter, I., Tucker, K.L., Arsenault, L., Bergethon, P., Bhadelia, R. et al. (2006) The Nutrition, Aging, and Memory in Elders (NAME) Study: Design and Methods for a Study of Micronutrients and Cognitive Function in a Homebound Elderly Population. International Journal of Geriatric Psychiatry, 21, 519-528. http://dx.doi.org/10.1002/gps.1503

[23] Statistisches Bundesamt (2013) Todesursachen. https://www.destatis.de/DE/ZahlenFakten/GesellschaftStaat/Gesundheit/Todesursachen/Todesursachen.html

[24] Reißmann, D.R., Heydecke, G. and van den Bussche, H. (2010) Die zahnärztliche Versorgung von Pflegeheimbewohnern in Deutschland-Eine kritische Würdigung der vorliegenden Studien. Deutsche Zahnärztliche Zeitschrift, 65, 647-653.

[25] Hallauer, J., Bienstein, C., Lehr, U. and Rönsch, H. (2005) SÄVIP-Studie zur ärztlichen Versorgung in Pflegeheimen. Vincentz Network Marketing Service, Hannover, 5-50. http://www.zukunftsforum-demenz.com/pdf/SAEVIP_studie.pdf

[26] Bourgeois, D., Nihtila, A. and Mersel, A. (1998) Prevalence of Caries and Edentulousness among 65-74-Year-Olds in Europe. Bulletin of the World Health Organ, 76, 413-417.

[27] Corsalini, M., Di Venere, D., Stefanachi, G., Tafuri, S. and Pettini, F. (2014) Clinical Evaluation and Orodental Status in a Group of Elderly Institutionalised Patients. Advances in Aging Research, 3, 199-207. http://dx.doi.org/10.4236/aar.2014.33028

[28] Katsoulis, J., Huber, S., Zumsteg, P., Pazera, P. and Mericske-Stern, R. (2009) Gerodontologischer Konsiliardienst bei stationären. Geriatriepatienten: Zahnmedizinischer Befund und zahnärztliche Massnahmen (II). Schweizer Monatsschrift für Zahnmedizin, 119, 688-694.

[29] Micheelis, W. and Schiffner, U. (2006) Vierte Deutsche Mundgesundheitsstudie (DMS IV). Deutscher Ärzte-Verlag, Köln.

[30] Wöstmann, B. (2003) Zahnersatz und Gesundheit bei Senioren. Zahnärztliche Mitteilungen, 93, 44-46.

[31] Elsig, F., Schimmel, M., Duvernay, E., Giannelli, S.V., Graf, C.E., Carlier, S., Herrmann, F.R., Michel, J.P., Gold, G., Zekry, D. and Müller, F. (2015) Tooth Loss, Chewing Efficiency and Cognitive Impairment in Geriatric Patients. Gerodontology, 32, 149-156. http://dx.doi.org/10.1111/ger.12079

[32] Kassenzahnärztliche Bundesvereinigung (2015) Zahnärzte und Bevölkerungszahlen (Kapitel 6). In: Jahrbuch 2014: Statistische Basisdaten zur vertragszahnärztlichen Versorgung, KZBV, Köln, 154.

[33] Nitschke, I., Ilgner, A., Wilde, F.J., Ritter, J. and Reiber, T. (2005) Zur Versorgung immobiler Patienten—Eine Befragung der Zahnärzte in Westfalen-Lippe. Deutsche Zahnärztliche Zeitschrift, 60, 292-297.

[34] De Visschere, L.M. and Vanobbergen, J.N. (2006) Oral Health Care for Frail Elderly People: Actual State and Opinions of Dentists towards a Well-Organised Community Approach. Gerodontology, 23, 170-176. http://dx.doi.org/10.1111/j.1741-2358.2006.00126.x

[35] Kassenzahnärztliche Bundesvereinigung (2008) Betriebswirtschaftliche Daten der Zahnarztpraxen. In: Jahrbuch 2007: Statistische Basisdaten zur vertragszahnärztlichen Versorgung, KZBV, Köln, 98-100.

[36] Ludwig, E. (2014) Alterszahnheilkunde und Prophylaxe: Wie sollte die Versorgung von Senioren heute und in Zukunft aussehen? https://www.seniorfirst.de/pdf/interviews/Interview-Dr-Ludwig.pdf

[37] Fiske, J. (2000) The Delivery of Oral Care Services to Elderly People Living in a Noninstitutionalized Setting. Journal of Public Health Dentistry, 60, 321-325. http://dx.doi.org/10.1111/j.1752-7325.2000.tb03342.x 